\title{
CARITATIVE SOCIAL WORK AS INNOVATION FROM ANTIQUITY
}

\author{
Skaidrīte Gūtmane \\ Latvian Christian Academy
}

\begin{abstract}
The article deals with the profession of Caritative social worker, its legitimate status in Latvia, as well with historical roots of the profession and its methodology. It is based on the Judeo-Christian anthropological paradigm and is reflected in European guidelines for Social work development, stemming from the founders' of the European Union concept of the Social stand of man and human dignity as spiritual subject.

KEY WORDS: caritative social work, innovation, Judeo-Christian anthropological paradigm, social cohesion.
\end{abstract}

\section{Anotacija}

Straipsnyje nagrinejjama socialinio darbuotojo profesija karitatyvinès veiklos kontekste, profesijos teisinis statusas Latvijoje, šios profesijos šaknys ir metododologija, pagrịsta judejjiška krikščioniška antropologine paradigma ir atsiskleidžia Europos socialinio darbo vystymo gairèse, kurios remiasi žmogaus socialinio vertingumo ir jo orumo, kaip dvasinio subjekto, koncepcija, apibrěžta pamatiniuose Europos Sajungos dokumentuose.

PAGRINDINIAI ŽODŽIAI: karitatyvinis socialinis darbas, inovacija, antropologinė judejjiška krikščioniška paradigma, socialinè sanglauda.

DOI: http://dx.doi.org/10.15181/tbb.v78i1.1760

\section{Introduction}

Profession "Caritative social work" was legally recognized in Latvia in December 20, 2007, when it was included in the Law of Social services and Social assistance. The Paragraph 1, p.16 defines Social work specialist as a "person having education prescribed by the Law and carrying out (...) professional duties (...) of a Caritative social worker". P.41 of the mentioned Law specifies that "persons with rights to carry out Social work must have the 2nd level higher professional or academic education in Social or Caritative social work". Ammendments to the Law of Social services and Social assistance from July 1, 2009, state that "Caritative social work is ANALOGUOUS TO SOCIAL WORK with a goal to help persons, families, groups or society in general to regain ability TO FUNCTION BOTH SOCIALLY AND SPIRITUALLY" (Emphasis mine - S. Gūtmane).

Following the mentioned norm of the Law the Caritative social work profession has clear anthropological focus, since "social and spiritual functioning" oversees specific field for both academic attention and professional activity, namely, 
integration of the awakened spiritual resources within a man into his/her social functioning. This task is directly linked to anthropological approach to a human personality.

As we all know the profession of a Social worker is called to promote social changes, to deal with inter-human relationships, to reveal and to strengthen the already-existing human potential with purpose to improve his/her well-being by application and use of various conceptual approaches to human behavior and social systems. Consequently the essence of Social work is rather complex and no wonder that in practice it experiences tensions between the focus on how to help, how to relax sufferings and distress of individuals caused either by structural oppression or unequality - on the one hand, and the individual need for empowerment and protection - on the other. Social work practice is a complex one. Every professional wants to deal with the case as a complex, whereas he is forced to admit that his efforts are not always succesful. Therefore, anthropological approach and its application in Social work profession as such, and in Caritative social work profession particularly should be taken as a professional activity of a very high importance. It is made possible only with clear understanding of and competence in meaningful forms and contexts of human relationships which have existed for centuries. In this all-encompassing source, meaningful forms, there are hidden values, which cannot be generalizedas we summarize facts, - these forms require special knowledgeoffered by onthological anthropology formulated during the Patristic period of the Christian Church.

Although the Social work profession is constantly changing and developing, its central function stays the same, namely, it promotes social changes, deals with problems of human relationships, activates clients' inner resources for his/her her own well-being. Caritative social worker exactly does the same job, however, his approach is based on two key vectors combined in mandatory wholeness: on the one hand, it activates resources for social functioning of the client, on the other - it activatesspiritual resources inherent in the client. Only then the professional task will be accomplished effectively, if these two vectors will integrate in one act. For successful implementation of this task rathervolumous anthropological knowledge is required.

\section{Caritative social work paradigm}

For better understanding of the Caritative social work paradigm a brief insight in its history is needed. It may be reminded that profession of Social worker started in the $19^{\text {th }}$ century Europe, encompassing various models for social welfare and protection, whereas Caritative social work goes back in thehistory several thousands of years ago when human society started to deal with the concept of margi- 
nalism and how to deal with it, how to help to recover one's spiritual and social functioning simultaneously. The root of this can be found in the Judeo-Christian anthropology and theology which dates back to ca. $6^{\text {th }}-7^{\text {th }}$ century BC in the writings of the Old Testament, in the New Testament $\left(1^{\text {st }}-2^{\text {nd }}\right.$ cent.), and this tradition has been polished to details insystematic academic discourse in the University of Alexandria $\left(2^{\text {nd }}-6^{\text {th }}\right.$ cent. $)$, and insinuated into the tradition of Ecumenical Christian Councils and anthropological pardigm of the Patristics. Judeo-Christian revelation was developing not only during the Patristic age, it was kept up by the Eastern Orthodox Christianity.

Patristic anthropology is not a descriptive science, it is related to onthological knowledge about man on three levels: first, within a phenomenon of social lifewhere human existance is taken in relational centexts; the second level clarifies perception of existance through analysis of practical enactment of both vertical and horizontal relationships; the third level is dynamics and processuality of man showing his capacity to reach the anthropological border of his/herexistance. Anthropological teaching of the Eastern Orthodoxy borrowed a lot from the idea about the onthological transformation of man, i.e., his capacity to step over the nature of the "fallen" man and to enter into the dimension of Deification (theosis in Greek).

The Judeo-Christian anthropology defines this concept as a process of "overcoming the self". It encompasses cognitions likeinner strength within a man which is expressed through self-sufficient singularity and spiritual potential. By rejection of its activation man loses foundation of his identity and experiences various depressive crisis throughout his life. Authors like Basil the Great, Gregory of Nyssa, Ireneus of Lyons and others elaborated anthropological concept of a Person and Hypostasis. During the period of Ecumenical Church Councils (till the $7^{\text {th }}$ cent.) the notion of "mutuality" (perihoresisin Greek, from the word "going in circle") was born, which describes human capacity to enter the dynamic process within the social context of mutuality.

Few words should be said about true anthropocentrism of the Biblical revelation. A man is not seen as a particular fragment or part of something bigger because he was installed in the center of the created world, and discourse about existance and fate of the world also is about the individual stand of each person. The goal and purpose of each man is described as his telos, in Patristic anthropology it means certain steps in one's spiritual growth which everyone marginalized or in crisis is capable to make. Stepping in in this process requires precise and well-founded methodology for activation of the client's anthropological resource for his/her own wellbeing. Analysis of the clients' situation requires adequate anthropological knowledge which is described as organon operated by Caritative social worker. 
Also in the context of the current Social work development due attention must be paid to both ancient roots of Caritative social work and proper understanding of what the well-known British mathematician and philosopher, spokesman for the 20th century science revolution Alfred North Whitehead has said about the culture of innovations: "Innovations are not born in times when they are discussed and when someone seeks for them and tries to implement. Like empires they are long gone, but they resurrect again today as a necessity. Innovative ideas always have travelled from ancient past when people have definitely forgotten them. Seek for innovative ideas in thousand-years ancient, I should say, in antique experience, where they are. You must single them out and adapt to the current age" (Whitehead, 1925). The same reasoning was supported by system analyst Emmanuel Wallerstein.

This is exactly what Latvian Christian academy did in 1993 when the Caritative social work education was launched on two pillars of knowledge:

1. Judeo-Christian anthropological concept of man and help to marginal persons,

2. The concept of man's social stand related to human dignity as a spiritual issue - the concept accepted by founders of European Union (Robert Schuman and others).

Theoretical and scientific foundations of the concept at the Academy were laid during first ten years of the Caritative social work profession development. The progress was burdened by the fact that under Soviet regime and in isolation Latvian specialists didn't know much neither about the Judeo-Christian concept of man, nor the intent of the European Union founders to promote cohesive and inclusive society in European countries. Consequently, the initiative of Latvian Christian academy to launch Caritative social work profession was met with atheism-based objections; examples may be given. We were pleased that professional conferences finally accepted general conjunctive decision that professional field of a Social worker should not be fragmented by separate standarts, and that both Social work and Caritative social work professions may mutually enrich each other.Of course, the author was surprised by reflections like: "Isn't so that Caritative social worker workslike pastor in the Church?" Also, specialists claimed that Social work should be based solely on humanist traditions. The author invited partners to return to dialogue as a dominating authority when common, mutually enriching development path must be taken rather than one truth is imposed by force. Democratic society presupposes multi-sided dialogue, whereas conflict-provoking attitudes destroys diversity of opinions in essence. The dialogue-open communication was initiated by DrHC of Latvian Christian academy Mrs. AijaBarča, Chairwoman of the Social and Employment Matters Committee (Latvian Parliament). Due to her competence 
high quality professional implications of Caritative social work were recognized as analoguousto the customary model of Social work which was supported by the College of Social Work "Attīstība" ("Development"). It should be noted that both Universities providing education in Social work - "Attīstība" and Latvian Christian academy - started their work in the same year.

\section{Historical roots of Caritative social work}

As noted before, Caritative social work has been the eldest Social work profession in the world and currently it is developed as diverse models in European welfare states under different titles: nursing (Charity sisters with theology-based knowledge), caritative counselor, pastoral counselor (with necessary knowledge for professional Social work), prison chaplain (with necessary knowledge for professional Social work) etc. In the United States of America Caritative social work is called "Christian social work", however, our understanding of Caritative social work doesn't match the American one due to clearly manifested Protestant perspective. We are critical to that and insist that Caritative social work has grown out of and is based on the Patristic onthological anthropology (Fig. 1).

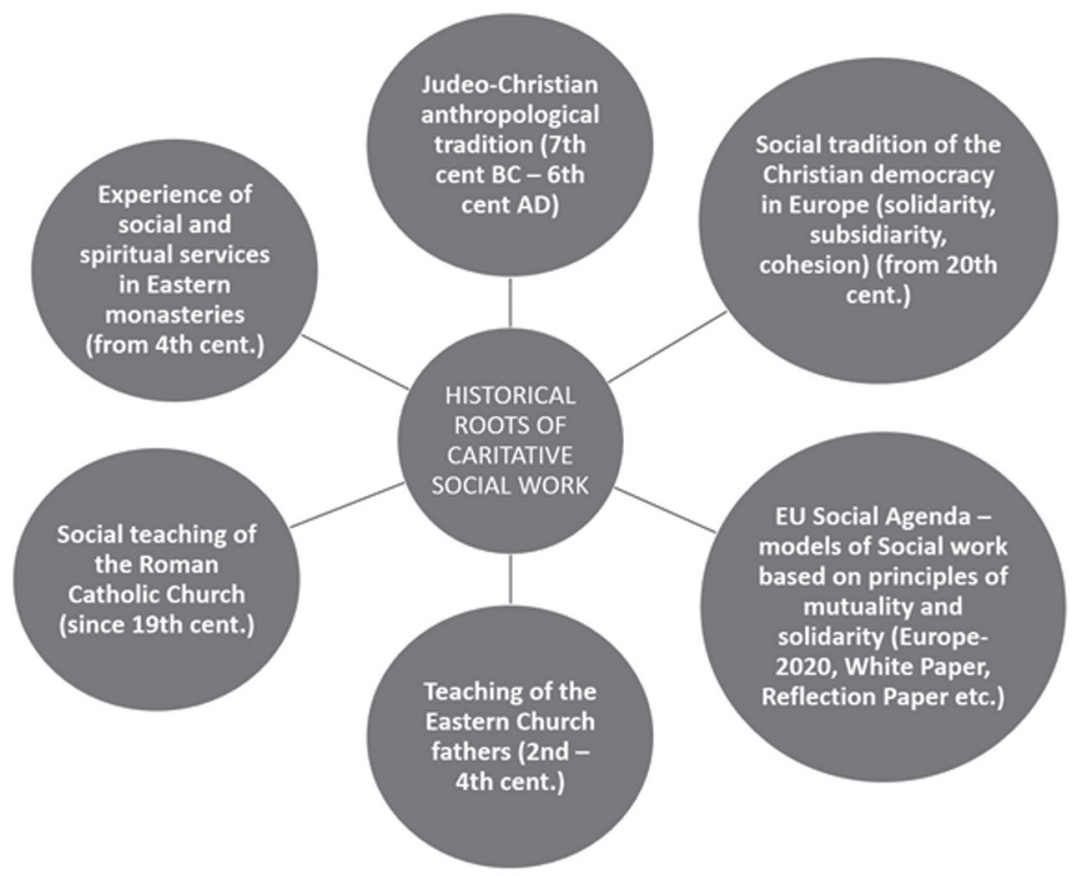

Fig. 1. Historical roots of Caritative social work are diverse 
Caritative social work has well-elaborated scientific and theoretical foundation. They are the following:

1. Professional activity based on interdisciplinary approach (Moral Theology, Systematic Theology, Psychology, Epistemology, Sociology, Social work as professional activity based on academic knowledge etc.).

2. Activity based on precise competence in Patristic anthropology.

3. Practical activity based on knowledge about diferences between a person and personality, and a knowledge about telos (goal with an effect) and knowledge about praxis (goal as a fact).

4. Practical activity based on knowledge of Ethics and Social sciences.

Making first steps in the Caritative social work development in Latvia the Academy wanted to put strong emphasis on the concept of Social care as the highest form of social phenomena, and self-understanding of a person and social onthology elaborated by existentialist philospher Martin Heidegger (De Jesus Silva, Vieira de Oliveira, Radunz, 2009; Danielle Conque, 2016; McNicollis, 1998) which surely corresponds to the Judeo-Christian stand, and deserves due attitude also today. However, objectives of Social care implementation in Latvia were formulated differently on political level byseparating it from the Social worker profession, therefore promotion of the of M. Heidegger's phenomenology within the context of Social work is a future task.

Caritative social work is not a science to safeguard general social welfare (Kīslings, 2000; Hirst, 1994; Schnappper, 2009; Schnapper, Bordes-Benayon, Raphael, 2010). Social work is a changing and developing profession, and it is more visible that, although both principles of human rights and social justice are fundamental to Social work profession, they are insufficient due to their simplified view on human relationships. As we know Social worker should treat his/ her clients neutrally, however, for Caritative social worker it is unthinkable - just because the client is his peer, neighbourwhose resources for further spiritual life should be activated. This goal is not achieved with neutral and impersonal attitude. For this goal methodology of cohesive mutuality is needed along with the context of identity where the specialist sees himself/herself in the situation of the other ("walks in his/her shoes," as saying goes).

It is more often that notions "mutuality", "identity", "spiritual changes" are used in the context of Social work. The author was pleased to hear that in debates in EU decision-making think-tank groups after the Meeting in Rome (2017) the following Social work definition was used, namely,the current Social work was described as a specific profession which analyses and promotes changes within a person urging social and spiritual changes in one's life, by relating problem solving with a family and other contexts of mutuality and identity. This working defi- 
nition precisely describes the field of professional activity carried out by Caritative social worker.

Both Bachelor and Master program students at Latvian Christian academy attend volumous courses in anthropology along with basic knowledge necessary for the Social work professional competence. These courses secure satisfying competences for proper understanding of spiritual, psychical and physical wholeness of man within the context of social changes and mutuality.

The main method used by Caritative social worker is that of Caritative and Social cohesion. "Caritative cohesion," as it is stated in the EC document "EC Social Agenda - Creating Synergies, 2014-2041", "is a societal duty because it promotes social position and progress of the marginal people". Latvian attitude to this innovative Social work form differs from that in other EU countries because Caritative social workers are not always employed as Social workers. Executive legislation should be improved for the benefit of Caritative social worker as provider of social services. We take it as misunderstanding that among providers of social services Caritative social worker is not mentioned side-by-side with a Social worker.

On the one hand, majority of Social workers stand on the concept of secular humanism. Surely, we have nothing against it, although secular humanism has proclaimed human rights on happiness while rejecting any source of power above man and his nature. Nevertheless, this imperative is not logical. Paul Kurtz, the author of "Manifesto of Secular Humanism", has defined onthological relativism and primacy of material well-being of people. The $3^{\text {rd }}$ Manifesto of Secular Humanism(containing 6 thesis)was published in 2003, whereP.Kurtz points out: "Humanism undergoes risk to stay as an interesting intellectual movement meant for limited number of scientists - philosophers executing little if any impact on practical life, because in eupraxsofia [Kurtz's term] should encompass both practice and theory, whereas humanism is only a movement of ideas" (Куртц, 2000). Also, it is probably not known to all that Judeo-Christian anthropology in its esence and contents is actually a socially active position rather than mere "movement of ideas", and it is oriented towards cohesion of society, i.e., inclusion of people, respect to people and their dignity, healing of marginalization, therefore nothing should be remarked.It is true that relations between the secular humanism and Judeo-Christian revelation always have enjoyed certain level of dialogue. If secular humanism turns away from its roots, it will turn into atheistic ideology and some kind of "religion" itself. And vice versa, where turning away from secular humanism happens, there is a danger to give birth to fanaticism and fundamentalism.

Unfortunately, further development of Social work profession in Latvia suffers from weariness. Weariness is called a kedia in Greek and it is close to the burnout syndrom when people are suppressed by fatigue and unwillingness to bring 
something new in their work routine. Actually, we should make crucial decision: do we want to lift the wholeness of the profession out of its historical roots and to work supportively and adequately for the benefit of the profession?

Sure, Social work profession is informed about Social and Cultural anthropology. Caritative social work implements its competence, but parallel to that turns to Judeo-Christian and Patristic anthropology which isonthological in its esence anddiffers from anthropology as mere social science. Patristic anthropology is meant for all humanity, it addresses all nations, it is not an anthropology as ethnology but rather pays attention to what is man in his/her essence. Caritative social work is both epistemologically and onthologically innovative approach to man in any social system and culture which works for better understanding of relations between a man and society. It describes man as both spiritual, psychic and physical being within social context, potentially capable to grow as personality or, vice versa, to stay on the level of individuum or mere person as a statistic unit (Хоружий, 1998).

Several analysts of Social work profession speak for the anthropological approach in Social work across Europe (in France, Great Britain, Belgium, also in the USA) (Beabout, 2003; Musil, 2006). The modern offer is anthropologically oriented Social work. Both anthropological and theological "technologies" exist along with more wide-spread social and information technologies, and their application can't be rated as unwise. Both phenomena and professions in humanitaries and social sphere are more interrelated rather than excluded due to the question how to activate both social and spiritual resources holistically. Caritative social work rejects the vogue concept "spirituality" and operates with the notion of "spiritual practice in man's life". This practice envisages concrete help to a client in his fight against the so-called psychic pathologies (deviances or, using the Patristic term, passions) aimed at guiding the client out from different levels of pathologies (passions) and crisis. (Analysis of pyschic pathologies or passions and related question of activation of spiritual resources deserve another treatise.)

Current discussions about welfare reforms and effectivity of them in Europe are related to discussions about foundations of human freedom and personality. Adequate understanding of those "foundations" is described as guarantee for effective welfare reforms (Beabout, 2003). For this reason, EC has welcomed partnership of Latvian Christian academy in several decision-making European organizations which promote holistic approach to man in society on higher poilitical level (SemainesSociales de France, EZA (European Center for Workers' Questions), IDC (International Diaconate Center), EESC (European Economic and Social Comittee).

In June 4, 2017, the author had a priviledge to attend the audience with PopeFranciscusin His Apostolic palace, Vatican. In His address to Caritative social 
workers His Eminency said: "Social workers need interdisciplinary knowledge with clear focus on both spiritual and ethical aspects. No-one will ever be able to solve social problems while spiritual needs will be ignored, because man is an onthologically spiritual entity."

\section{Literature}

Beabout, G. R. (2003). The Role of Christian Anthropology in Welfare Reform. Acton Institute Policy Forum, Vol. 4. Retrieved: https://www.catholiceducation.org/en/religion-and-philosophy/social-justice/the-role-ofchristian-anthropology-in-welfare-reform.html

Danielle Conque, A. (2016). The Parth Not Taken: Martin Heidegger \& a Politics of Care. Lousiana State University, LSU Digital Commons, 248 p. Retrieved: www.digitalcommons.edu.

De Jesus Silva, I., Vieira de Oliveira, M., Radunz, V. (2009). Care, self-care and caring for yourself: a paradigmatic understanding thought for nursing care. Rev Esc Enferm USP, Vol. 43(3), p. 46-84. Retrieved: pdfs. semanticscholar.org

Hirst, P. (1994) Associative Democracy: New Forms of Economic and Social Governance. Cambridge: Polity Press, $222 \mathrm{p}$.

Kīslings, K. (2001). Jūssveicinamīlestība: Raksti par diakoniskukultūru. Jūrmala: Latvijas Kristīgā akadēmija, $240 \mathrm{lpp}$.

McNicollis, C. F. (1998). Self-understanding and the Care for Being: Heidegger's Ethical Thought. McMaster University, 235 p. Retrieved: www.macsphere.mcmaster.ca

Musil, L. (2006). Coping with Dilemmas: Working Conditions and Interactions of Social Workers with their Clients. Institut fur vergleichende Social arbaits wissen schaft und interkulturelle / internationaleSozialarbeit (ISIS), $129 \mathrm{~S}$.

Schnapper, D. (2009) Providential Democracy: An Essay on Contemporary Equality. New Jersey: Transaction Publ., 234 p.

Schnapper, D., Bordes-Benayon, Ch., Raphael, F. (2010). Jewish Citizenship in France: The Temptation of Being among One's Own. New Brunswick: Transaction Publ., 140 p.

Whitehead, A. N. (1925). Science and the Modern World. N.Y.: Macmillan Company, 560 p.

Куртц, П. (2000). Мужество стать: Добродетели гуманизма. Москва, 150 с.

Хоружий, С. (1998). К феноменологии аскезы. Москва, 208 с. 
